\title{
In silico analysis of candidate genes associated with humoral innate immune response in chicken
}

\author{
Anna Slawinska ${ }^{1 *}$, Andrzej Witkowski ${ }^{2}$, Marek Bednarczyk ${ }^{1}$, Maria Siwek ${ }^{1}$ \\ From International Symposium on Animal Genomics for Animal Health (AGAH 2010) \\ Paris, France. 31 May - 2 June 2010
}

\begin{abstract}
Background: Production and function of natural antibodies (NAbs) constitutes an important mechanism of the humoral innate immunity in vertebrates. The level of NAbs in chicken is heritable and the genetic background has been partly investigated. However, to date the genetic determination of humoral innate immune response in avian species has not been fully described. The goal of this study was to propose a new set of candidate genes with a potential effect on the NAb phenotype for further SNP association study.

Methods: In silico analysis of positional and functional candidate genes covered 14 QTL regions associated with LPS, LTA \& KLH NAbs and located on six chromosomes: GGA5, GGA6, GGA9, GGA14, GGA18 and GGAZ. The function of the genes was subsequently determined based on the NCBI, KEGG, Gene Ontology and InnateDB databases.

Results: As a result, the core panel of 38 genes participating in metabolic pathways of innate immune response was proposed. Most of them were assigned to chromosomes: GGA14, GGA5, GGA6 and GGAZ $(13,9,8$ and 5 genes, respectively). These candidate genes encode proteins predicted to play a role in (i) proliferation, differentiation and function of B lymphocytes; (ii) TLR signalling pathway, and (iii) MAP signalling cascade.

Conclusions: Proposed set of candidate genes is recommended to be included in the follow-up studies to model genetic networks of innate humoral immune response in chicken.
\end{abstract}

\section{Background}

Humoral innate immunity in vertebrates that establishes the first barrier against pathogens consists of two basic mechanisms - natural antibodies (NAbs) and complement system. Expanding the knowledge on this field of avian immunology might be of help to overcome the difficulties in poultry industry, struggling constantly with diseases outbreaks eg. Avian Influenza [1]. In chicken, the level of NAbs proved to be heritable [2]. However, the genetic determination of NAbs is not fully described as it lacks information on which genes can be considered as the regulators in the complicated network of NAbs creation and function. This study contributes to the discovery of genetic determination of humoral

\footnotetext{
* Correspondence: anna.slawinska@utp.edu.pl

'Department of Animal Biotechnology, University of Technology and Life Sciences, Bydgoszcz, 85-084, Poland

Full list of author information is available at the end of the article
}

innate immunity as it lists the proposed positional and functional candidate genes that have the putative impact on the NAb phenotype.

\section{Methods}

Chromosomal regions for in silico candidate gene analysis were initially selected based on the location of the QTL associated with the NAb titres directed against LPS (lipopolysaccharide), LTA (lipoteichoic acid) and KLH (keyhole limpet hemocyanine) antigens in chicken. This step was performed based on results from two independent studies, i.e.

- Study 1 - LPS and LTA NAb QTL detection study [3];

- Study 2 - LPS and LTA NAb QTL validation study; KLH NAb detection study (data not published).

Study 2 was carried out within a new chicken reference population, set-up as a $F_{2}$ cross between

\section{Ciomed Central}


Table 1 Positional and functional candidate genes associated with innate humoral immune response

\begin{tabular}{|c|c|c|c|c|c|}
\hline Symbol & ID & Name & $\mathrm{Ch}$ & Metabolic Pathway & Gene Function \\
\hline BLNK & 395733 & B cell linker & 6 & $\mathrm{BCR}$ & B-cell development \\
\hline CARD11 & 416476 & $\begin{array}{l}\text { caspase recruitment domain family, } \\
\text { member } 11\end{array}$ & 14 & $\mathrm{BCR}, \mathrm{TCR}, \mathrm{NF} \kappa \mathrm{B}$ & $\mathrm{NF} \kappa \mathrm{B}$ activation \\
\hline CASP7 & 423901 & $\begin{array}{l}\text { caspase } 7 \text {, apoptosis-related cysteine } \\
\text { peptidase }\end{array}$ & 6 & $\mathrm{BCR}, \mathrm{TNF} \alpha$ & Apoptosis \\
\hline CAT & 423600 & Catalase & 5 & $\mathrm{NF} \kappa \mathrm{B}$ & Regulation of $\mathrm{NF} \kappa \mathrm{B}$ activity \\
\hline CD59 & 423148 & $\begin{array}{l}\text { CD59 molecule, complement } \\
\text { regulatory protein }\end{array}$ & 5 & T cells & T cell activation, complement system inhibition \\
\hline CD7 & 417346 & T-cell antigen CD7 precursor & 18 & T cells & $\begin{array}{l}T \text { cell activation, } T \text { and } B \text { cell interaction, } \\
\text { component of mature } T \text { cells }\end{array}$ \\
\hline CD82 & 423172 & CD82 molecule & 5 & $\mathrm{NF} \kappa \mathrm{B}, \mathrm{p} 53$ & Binding of proteins in cell membrane \\
\hline CIITA & 427676 & $\begin{array}{l}\text { class II, major histcompability } \\
\text { complex, transactivator }\end{array}$ & 14 & TLR, MHC & LRR binding, MHCII transcription activation \\
\hline CXCL12 & 395180 & chemokine (C-X-C motif) ligand 12 & 6 & IL & $\begin{array}{l}\text { Leukocyte activation, } T \text { cell proliferation, } \\
\text { chemotaxis }\end{array}$ \\
\hline FADD & 423146 & $\begin{array}{l}\text { FAS (TNFRSF6)-associated via death } \\
\text { domain }\end{array}$ & 5 & $\mathrm{NF} \kappa \mathrm{B}$ & $\begin{array}{l}\text { Apoptosis, NF } \kappa \text { B cascade activation, early } \\
\text { development of T cells }\end{array}$ \\
\hline FAS & 395274 & TNF receptor superfamily, member 6 & 6 & TNF $\alpha$, Fas, B and T cells & $\begin{array}{l}\text { Ig production, immune response with (B cells) } \\
\text { Homeostasis between B I T cells }\end{array}$ \\
\hline FGF10 & 395432 & fibroblast growth factor 10 & Z & $\mathrm{NF} \kappa \mathrm{B}, \mathrm{MAPK}$ & $\begin{array}{l}\text { TLR activation, inflammatory cytokine secretion } \\
\text { (with APC) }\end{array}$ \\
\hline FGF8 & 396313 & fibroblast growth factor 8 & 6 & MAPK & MAPK cascade activation \\
\hline FOS & 396512 & $\begin{array}{l}\text { v-fos FBJ murine osteosarcoma viral } \\
\text { oncogene homolog }\end{array}$ & 5 & TLR, BCR, TCR, MAPK, JNK, IL & Synthesis of AP-1 transcription factor \\
\hline IGSF6 & 771906 & immunoglobulin superfamily, mem. 6 & 14 & $B$ and $T$ cells & Membrane receptor of $\mathrm{T}$ and $\mathrm{B}$ cells \\
\hline IL20RB & 768437 & interleukin 20 receptor beta & 14 & Jak-STAT, IL & $\mathrm{T}$ and $\mathrm{B}$ cells proliferation and differentiation \\
\hline IL21R & 416586 & interleukin 21 receptor & 14 & Jak-STAT, IL & $\mathrm{T}$ and $\mathrm{B}$ cells proliferation and differentiation \\
\hline IL31RA & 427140 & interleukin 31 receptor $A$ & Z & MAPK, Jak-STAT, IL & $\begin{array}{l}\text { MAPKKK cascade, cytokine and chemokine signal } \\
\text { transduction, monocyte and macrophage } \\
\text { differentiation }\end{array}$ \\
\hline IL4R & 416585 & interleukin 4 receptor & 14 & T cells, IL & Th2 lymhocyte differentation, cytokine receptor \\
\hline IL6ST & 395684 & interleukin 6 signal transducer & Z & $\mathrm{IL}$ & Fragment of cytokine receptor complex \\
\hline IL9R & 416587 & interleukin 9 receptor & 14 & Jak-STAT, IL & Jak and STAT activation, cytokine receptor \\
\hline JAK2 & 374199 & Janus kinase 2 & Z & Jak-STAT, IL & Cytokine signalling \\
\hline LITAF & 374125 & lipopolysaccharide induced TNF factor & 14 & $\mathrm{TNF} \alpha$ & TNF $\alpha$ expression \\
\hline MAP2K3 & 416496 & $\begin{array}{l}\text { Mitogen activated protein kinase } \\
\text { kinase } 3\end{array}$ & 14 & $\begin{array}{l}\text { MAPK, TLR, JNK, Fc, p38, } \\
\text { TNF } \alpha \text {, Jak-STAT, TRAIL }\end{array}$ & MAPKKK cascade \\
\hline MAP2K4 & 417312 & $\begin{array}{l}\text { Mitogen activated protein kinase } \\
\text { kinase } 4\end{array}$ & 18 & $\begin{array}{l}\text { MAPK, TLR, Fas, JNK, FC, TCR, } \\
\text { Jak-STAT, TRAIL }\end{array}$ & $\begin{array}{l}\text { MAP kinase activation, in response to different } \\
\text { stimuli, survival signal for T cells }\end{array}$ \\
\hline MAP3K1 & 427144 & $\begin{array}{l}\text { mitogen activated protein kinase } \\
\text { kinase kinase } 1\end{array}$ & Z & $\begin{array}{l}\text { MAPK, TLR, Fas, JNK, Fc, p38, } \\
\text { NF } \kappa B \text {, TCR, BCR, INF } \gamma \text {, TRAIL, } \\
\text { TNF } \alpha\end{array}$ & $\begin{array}{l}\text { Integration of enzyme fosforylation in response } \\
\text { to different factors }\end{array}$ \\
\hline MAP3K 13 & 424876 & $\begin{array}{l}\text { mitogen-activated protein kinase } \\
\text { kinase kinase } 13\end{array}$ & 9 & MAPK, JNK & Activation of different MAP kinases \\
\hline MAPK8 IP3 & 426986 & $\begin{array}{l}\text { mitogen-activated protein kinase } 8 \\
\text { interacting protein } 3\end{array}$ & 14 & MAPK, JNK & MAPK and JNK integration \\
\hline NFKBIA & 396093 & $\begin{array}{l}\text { nuclear factor of kappa light } \\
\text { polypeptide gene enhancer in B-cells } \\
\text { inhibitor, alpha }\end{array}$ & 5 & $\mathrm{TLR}, \mathrm{BCR}, \mathrm{TCR}, \mathrm{NF} \kappa \mathrm{B}$ & $\mathrm{NF} \kappa \mathrm{B}$ Inhibitor \\
\hline PDCD4 & 374191 & $\begin{array}{l}\text { programmed cell death } 4 \text { (neoplastic } \\
\text { transformation inhibitor) }\end{array}$ & 6 & JNK & $\begin{array}{l}\text { Negative JNK regulation, expression of the gene } \\
\text { under control of T cells }\end{array}$ \\
\hline RAG2 & 423165 & recombination activating gene 2 & 5 & $B$ and $T$ cells & $\begin{array}{l}\text { B and } T \text { cells differentiation, gene conversion in } \\
\lg \end{array}$ \\
\hline RBP4 & 396166 & retinol binding protein 4, plasma & 6 & B cells & Activation of Ig secretion \\
\hline SOCS1 & 416630 & supressor of cytokine sygnalling 1 & 14 & Jak-STAT, IL & $\begin{array}{l}\text { Inhibition of cytokine secretion \& Jak-STAT } \\
\text { cascade }\end{array}$ \\
\hline TCF7L2 & 395508 & Transcription factor 7-like 2 & 6 & WNT & WNT signalling \\
\hline
\end{tabular}


Table 1 Positional and functional candidate genes associated with innate humoral immune response (Continued)

\begin{tabular}{|c|c|c|c|c|c|}
\hline TGFB3 & 396438 & transforming growth factor, beta 3 & 5 & MAPK, TGF $\beta$, GPCR & MAPK activation, growth factor activity \\
\hline TNFRSF13B & 770275 & $\begin{array}{l}\text { TNF receptor superfamily, member } \\
13 \mathrm{~B}\end{array}$ & 14 & $\mathrm{AP}-1, \mathrm{NF} \kappa \mathrm{B}, \mathrm{TNF}$ & Key role in humoral immune response \\
\hline TRAF6 & 423163 & TNF receptor-associated factor 6 & 5 & TNF, TLR, IL, NF $\kappa B, T C R$ & $\begin{array}{l}\text { Signal transduction in many pathways, Th1 } \\
\text { immune response, } T \text { cell activation }\end{array}$ \\
\hline TRAF7 & 416555 & TNF receptor-associated factor 7 & 14 & TNF & MAPKKK cascade activation \\
\hline
\end{tabular}

Gene symbol, ID and name according to NCBI database; Ch - chromosome number, Metabolic Pathway and Gene Function based on GO and InnateDB.

commercially selected breed (WL, White Leghorn) and a Polish, unselected native chicken breed (GP, Greenlegged Partridgelike). For a candidate gene analysis reported here, the chromosomal regions of interest included QTL associated with LPS and LTA NAb titres that had been detected in study $\mathbf{1}$ and consecutively validated in study $\mathbf{2}$ as well as QTL associated with KLH NAb titres that had been detected in study 2 . These QTL were located in the following chicken chromosomes: GGA5, GGA6, GGA9, GGA14, GGA18 and GGAZ. The regions of interest were designated based on the physical location of the microsatellite markers flanking the QTLs. The list of candidate genes within the QTL regions was prepared based on NCBI database [4], and gene function was assessed with KEGG [5], InnateDB [6] and Gene Ontology [7]. The genes meeting both the criteria, i.e. location within the QTL regions \& function in innate immunity (including signalling pathways and B cell function) were listed in a panel of the candidate genes associated with humoral innate immune response.

\section{Results}

The results of the candidate gene analysis are presented in Table 1. Briefly, based on previously described criteria, the total number of 38 candidate genes located on six chromosomes was selected. The highest number of the candidate genes (13 genes) was located on GGA14; 9 genes were found on GGA5 and 8 - on GGA6. Lower number of candidate genes were found on GGAZ (5 genes), on GGA18 (2 genes) and on the GGA9 (1 gene).

It can be summarized that these candidate genes encode proteins predicted to play a role in:

(i) Proliferation, differentiation and function of B lymphocytes, e.g. CXCL12, BLNK, IL21R, RBP4, CD59, TNFRSF13B;

(ii) TLR signalling pathway, e.g. TRAF6, FADD, NFאBIA, CARD11, FAS, FGF8, TGFB, IL31RA;

(iii) MAP signalling cascade, e.g. $M A P 2 K 3, M A P 2 K 4$, МАРЗК1, МАРЗК13, МАРК8IP3.

\section{Discussion}

Immune response is a complicated process; encoded by multiple genes organized within the frames of functional networks rather than pathways and regulated by many interactions. However, prior to modelling the most probable genetic network, the information is needed on the genes that can be taken into account and their physiological function.

As mentioned above, the function of the proposed set of candidate genes was associated with three groups of cellular and physiological processes that can hypothetically affect innate humoral immune response in chicken. Briefly, production of antibodies, including NAbs takes place in B cells, stimulated by Th2 cytokines. Therefore, both $\mathrm{B}$ and $\mathrm{T}$ cells function is a crucial element in antibody release. CXCL12 gene is responsible for B cells proliferation [8]. CXCL12 $2^{-/-}$knockout mice produced drastically reduced number of $B$ cells and died during the perinatal period [9]. In turn, BLNK gene affects $\mathrm{B}$ cell development, which was completely inhibited in $B L N K^{-1-}$ knockout mouse [10]. Finally, IL21R and RBP4 genes are responsible for maintenance of mature $B$ cells function. Knocked out mice (both $I L 21 R^{-/-}$and $R B P 4^{-/-}$) expressed impaired production of antibodies [11,12].

TLR signalling pathway is triggered when molecular patterns (such as LPS or LTA) are recognized. Some of the proposed candidate genes are involved in TLR pathway, just to mention TRAF6 and FADD, as well as genes affecting $N F \kappa B$ expression and function, such as NFKBIA, CARD11, TNFRSF13B and FAS[13-15]. Furthermore, the analysis in silico pointed out a number of genes that activate MAPK cascade, a key signalling pathway initiated by TLR, for example FGF8, TGFB3 and IL31RA[14]. Additionally, the candidate gene set includes such genes as MAP2K3, MAPK8IP3, MAP $3 K 13$, $M A P 2 K 4$ and $M A P 3 K 1$, which are the members of MAPK signal transduction pathway [15].

\section{Conclusions}

Chicken immune response is one of the major areas recently studied in life science research related to livestock. So far, different approaches have been applied to dissect the genetic bases of avian health traits. Rapid development of technology supporting high-throughput genomic studies provided an excellent tool for fast and efficient genotyping. Still, the accurate gene selection can pose a problem. Therefore, the additional criteria, like validated QTL regions may be of assistance to list the proper genes that can be further on evaluated and 
contribute to genetic network modelling of humoral immune response in chicken. For that reason we proposed a panel of candidate genes related to the level of LPS, LTA \& KLH NAbs in chicken.

\section{Acknowledgements}

The study supported by the State Committee for Scientific Research (grant no. P 06D 012 30) and by the Integrated Regional Development Programme (grant no. SPS.IV-3040-UE/S05/2009)

This article has been published as part of BMC Proceedings Volume 5 Supplement 4, 2011: Proceedings of the International Symposium on Animal Genomics for Animal Health (AGAH 2010). The full contents of the supplement are available online at http://www.biomedcentral.com/1753$6561 / 5$ ? issue $=\$ 4$

\section{Author details}

'Department of Animal Biotechnology, University of Technology and Life Sciences, Bydgoszcz, 85-084, Poland. 'Department of Biological Bases of Animal Production, University of Life Sciences, Lublin 20-950, Poland.

\section{Authors' contributions}

AS performed the analysis and drafted the manuscript; AW made substantial contributions to acquisition of data; MB participated in the design of the study; MS conceived of the study, participated in its design and coordination and helped to draft the manuscript.

\section{Competing interests}

The authors declare that they have no competing interests.

Published: 3 June 2011

\section{References}

1. Gauthier-Clerc M, Lebarbenchon C, Thomas F: Recent expansion of highly pathogenic avian influenza H5N1: a critical review. Int. J. Avian Sci 2007, 149:201-214.

2. Parmentier HK, Lammers A, Hoekman JJ, de V Reilingh G, Zaanen ITA, Savelkoul HFJ: Different levels of natural antibodies in chickens divergently selected for specific antibody responses. Dev. Comp. Immunol 2004, 28:39-49.

3. Siwek M, Buitenhuis B, Cornelissen S, Nieuwland M, Knol EF, Crooijmans R, Groenen M, Parmentier H, van der Poel J: Detection of QTL for innate: non-specific antibody levels binding LPS and LTA in two independent populations of laying hens. Dev. Comp. Immunol 2006, 30:659-66.

4. National Center for Biotechnology Information:[http://www.ncbi.nlm.nih. gov].

5. Kanehisa M, Goto S: KEGG: kyoto encyklopedia of genes and genomes. Nucleic Acids Res 2000, 28:27-30

6. Lynn DJ, Winsor GL, Chan C, Richard N, Laird MR, Barsky A, Gardy JL, Roche FM, Chan THW, Shah N, Lo R, Naseer M, Que J, Yau M, Acab M, Tulpan D, Whiteside MD, Chikatamarla A, Mah B, Munzner T, Hokamp K, Hancock REW, Brinkman FSL: InnateDB: facilitating systems-level analyses of the mammalian innate immune response. Mol. Syst. Biol 2008, 4:218.

7. Gene Ontology Consortium: Creating the gene ontology resource: design and implementation. Genome Res 2001, 11:1425-33.

8. Ma Q, Jones D, Borghesani PR, Segal RA, Nagasawa T, Kishimoto T, Bronson RT, Springer TA: Impaired B-lyphopoiesis, myelopoiesis, and derailed cerebellar neuron migration in CXCR4- and SDF-1-deficient mice. PNAS 1998, 95:9448-53.

9. Nagasawa T, Hirota S, Tachibana K, Takakura N, Nishikawa S, Kitamura Y, Yoshida N, Kikutani H, Kishimoto T: Defects of B-cell lymphopoiesis and bone-marrow myelopoiesis in mice lacking the CXC chemokine PBSF/ SDF-1. Nature 1996, 382:635-8.

10. Pappu R, Cheng AM, Li B, Gong Q, Chiu C, Griffin N, White M, Sleckman BP, Chan AC: Requirement for B Cell Linker Protein (BLNK) in B Cell Development. Science 1999, 286:1949-54.

11. Quadro L, Gamble MV, Vogel S, Lima AAM, Piantedosi R, Moore SR, Colantuoni V, Gottesman ME, Guerrant RL, Blaner WS: Retinol and RetinolBinding Protein. Gut Integrity and Circulating Immunoglobulins. I Infect Dis 2000, 182 Suppl 1:S97-S102.
12. Ozaki K, Spolski R, Feng CG, Qi CF, Cheng J, Sher A, Morse HC 3rd, Liu C, Schwartzberg PL, Leonard WJ: A critical role for IL-21 in regulating immunoglobulin production. Science 2002, 298:1630-4.

13. Li X, Stark GR: NFKB-dependent signaling pathway. Exp. Hematol 2002, 30:285-96.

14. Cormican P, Lloyd AT, Downing T, Connell SJ, Bradley D, O'Farrelly C: The avian Toll-Like receptor pathway-subtle differences amidst general conformity. Dev Comp Immunol 2009, 33:967-73.

15. Lynn DJ, Lloyd AT, O'Farrelly C: In silico identification of components of the Toll-like receptor (TLR) signaling pathway in clustered chicken expressed sequence tags (ESTs). Vet Immunol Immunopathol 2003, 93:177-84

16. Massagué J: Integration of Smad and MAPK pathways: a link and a linker revisited. Genes Dev 2003, 17:2993-7.

17. Liu Y, Shepherd EG, Nelin LD: MAPK phosphatases-regulating the immune response. Nat. Rev. Immunol 2007, 7:202-12

doi:10.1186/1753-6561-5-S4-S36

Cite this article as: Slawinska et al:: In silico analysis of candidate genes associated with humoral innate immune response in chicken. BMC Proceedings 2011 5(Suppl 4):S36.

\section{Submit your next manuscript to BioMed Central and take full advantage of:}

- Convenient online submission

- Thorough peer review

- No space constraints or color figure charges

- Immediate publication on acceptance

- Inclusion in PubMed, CAS, Scopus and Google Scholar

- Research which is freely available for redistribution
Ciomed Central 